\title{
Fc Receptor-Like Protein 5
}

National Cancer Institute

\section{Source}

National Cancer Institute. Fc Receptor-Like Protein 5. NCI Thesaurus. Code C123874.

Fc receptor-like protein 5 (977 aa, $\sim 106 \mathrm{kDa}$ ) is encoded by the human FCRL5 gene. This protein may play a role in the regulation of B-cell-mediated immunity. 